\title{
Analysis of drag and lift forces for a sedan car using a rear lip spoiler
}

\section{Análisis de fuerzas de arrastre y sustentación para un auto sedan usando alerón trasero tipo labio}

HORTELANO-CAPETILLO, Juan Gregorio †*, MARTÍNEZ-VÁZQUEZ，J. Merced，ZUÑIGACERROBLANCO, José Luis and RODRIGUEZ-ORTIZ, Gabriel

Universidad Politécnica de Juventino Rosas, Mexico.

ID $1^{\text {st }}$ Author: Juan Gregorio, Hortelano-Capetillo / ORC ID: 0000-0002-3702-4853, CVU CONACYT ID: 347496

ID $1^{\text {st }}$ Co-author: J. Merced, Martínez-Vázquez / ORC ID: 0000-0002-6230-3846, CVU CONACYT ID: 93450

ID $2^{\text {nd }}$ Co-author: José Luis, Zúñiga-Cerroblanco / ORC ID: 0000-0003-0493-8197, CVU CONACYT ID: 208410

ID $3^{\text {rd }}$ Co-author: Gabriel, Rodriguez-Ortiz / ORC ID: 0000-0002-3615-1973, CVU CONACYT ID: 48565

DOI: $10.35429 / \mathrm{JME} .2020 .13 .4 .23 .31$

Received January 25, 2020; Accepted June 30, 2020

\begin{abstract}
In this research, aerodynamic tests were carried out using Solidworks Flow Simulation software on a Sedan-type car, implementing different sizes of liptype spoilers at the rear to obtain the results of the drag and lift coefficients produced by movement. of the air regardless of the design at the rear of the car and analyze if there was improvement in aerodynamics. Analyzing the results, it is obtained that the aerodynamics of the car is improved when a lip-type spoiler is fitted, the lift forces were reduced, whereas the drag forces remained constant for all the different designs.
\end{abstract}

Drag coefficient, Lift coefficient, Aerodynamics

\begin{abstract}
Resumen
En esta investigación se realizaron pruebas aerodinámicas mediante el uso del software Solidworks Flow Simulation en un automóvil tipo Sedan, implementando diferentes tamaños de aleron tipo labio en la parte trasera para obtener los resultados de los coeficientes de arrastre y de sustentación que se producen mediante el movimiento del aire independientemente del diseño en la parte trasera del auto y analizar si hubo mejora en la aerodinámica. Analizando los resultados se obtiene que se mejora la aerodinámica del automóvil cuando se le pone un alerón tipo labio, se redujo las fuerzas de sustentación, en cambio las fuerzas de arrastre se mantuvieron constante para todos los diferentes diceños.
\end{abstract}

Coeficiente de arrastre, Coeficiente de sustentación, Aerodinámica

Citation: HORTELANO-CAPETILLO, Juan Gregorio, MARTÍNEZ-VÁZQUEZ, J. Merced, ZUÑIGA-CERROBLANCO, José Luis and RODRIGUEZ-ORTIZ, Gabriel. Analysis of drag and lift forces for a sedan car using a rear lip spoiler. Journal of Mechanical Engineering. 2020. 4-13:23-31.

\footnotetext{
* Correspondence to the Author (Email: jhortelano_ptc@upjr.edu.mx)

$\uparrow$ Researcher contributing as first author.
} 


\section{Introduction}

The ailerons have different configurations and sizes, in some cases they are already assembled from the factory. When the car is in motion, it creates a flow of air that surrounds the body and is usually trapped at the bottom, which creates an upward pressure in the front, reducing the forces on the tires against the ground. To solve this aerodynamic problem is to relieve the pressure by implementing the ailerons at the rear, in this way, the flow of air passes under the wing that will have a speed greater than the air that passes over it creating a downward force called lift. There are 2 methods to perform the aerodynamic tests and obtain the drag and lift forces:

\section{- $\quad$ Wind tunnel.}

- CFD (Computational Fluid Dynamics) techniques.

Using a wind tunnel, it simulates in a real way the air currents that are generated at different speeds against the vehicle that remains static. On some occasions smoke is used to be able to observe turbulence clearly. Using the method in CFD is the use of computers as tools to solve the equations of fluid dynamics, having the advantage of being able to see the current lines, vortices, pressure fields around the vehicle, etc.

In automotive aerodynamics, its main objective is to decrease drag and lift coefficients for fuel economy, this phenomenon allows the car conditions to be faster using the same power. Howell et al [1] and Okada et al [2] took the dynamic movement of the vehicle into account to consider stability problems, whereas Aschwanden et al [3] carried out the measurements in a wind tunnel. Studies on car designs to improve aerodynamics have been advancing all the time, because aerodynamic performance is directly related to fuel consumption and environmental impact.

Scale experiments carried out in a wind tunnel are the most common methods for investigating the aerodynamics of vehicles $[3,4$, $5,6,7,8]$. Some researchers implemented some devices such as spoilers, ailerons or fins; to improve aerodynamics $[9,10,11,12,13]$, other authors investigated the impact on the deflectors horizontally $[14,10]$.
Some studies carried out to improve aerodynamics are in the rear diffuser, located under the bodywork modifying the angles and the shape of the spacers to affect the flow formed by the air speed [15, 16, 17]. Some researchers Gilhauset al. [18], J. R. Callister et al. [19], F. R. Bailey et al. [20], H. Taeyoung et al. [21], S. Y. Cheng et al. [22], S. M. Rakibul Hassan [23], Rubel et al. [24], D. E. Aljure et al. [25], Krzysztof Kurec et al. [26], Vignesh S. et al. [27], Mario et al. [28], Emil Ljungskog et al. [29], among others, used CFD techniques to obtain numerical results of the cars by making modifications to the design.

\section{Mathematical and numerical model}

In this work, several tests were carried out in CFD to reproduce the aerodynamic behavior for the different models with the implementation of a spoiler. Figure 1 shows the steps to solve a problem using CFD.

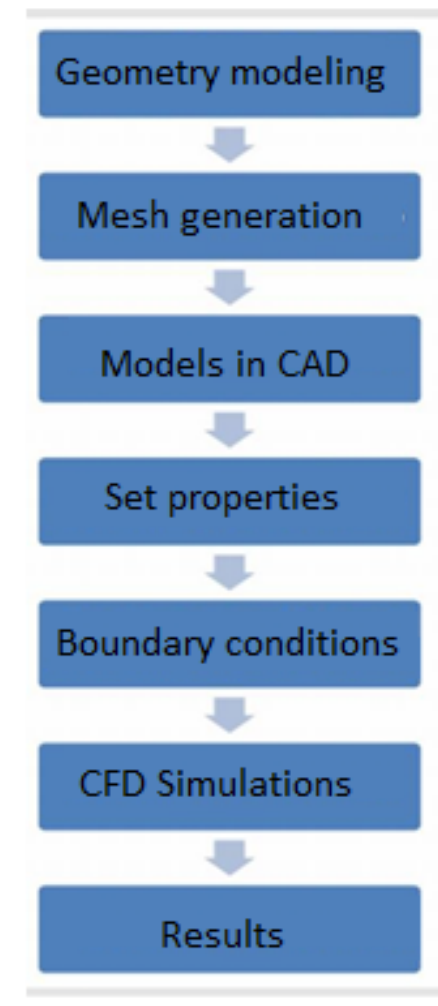

Figure 1 Steps for simulation in CFD Source: Self-made

A sedan car was designed without any implement in Solidworks, as shown in Figure 2, the dimensions are $4.63 \mathrm{~m}$ long, $1.74 \mathrm{~m}$ wide and $1.36 \mathrm{~m}$ high, giving a frontal area of $2.36 \mathrm{~m}^{2}$. 


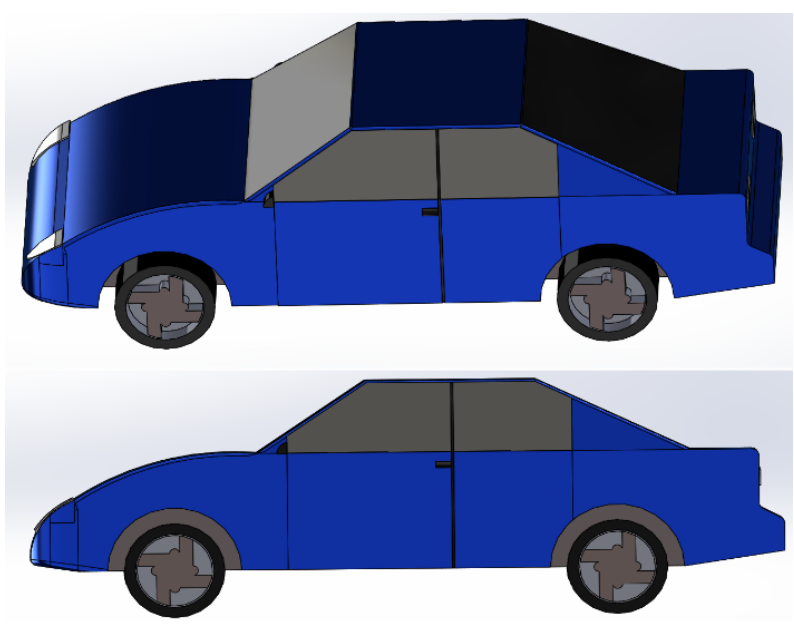

Figure 2 Normal Design

Source: Own elaboration in Solidworks

Figure 3 shows an example of the liptype spoiler placed at the rear of the car to improve aerodynamics by reducing drag and lift forces.

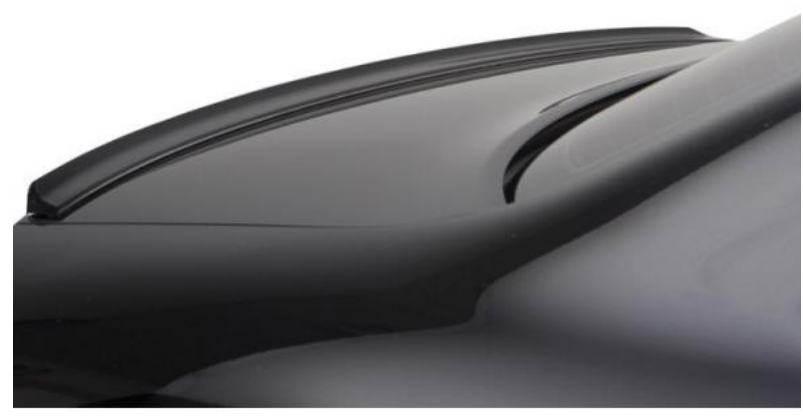

Figure 3 Design of a lip type spoiler

Source: Own elaboration in Solidworks

6 different models of lip-type spoilers were designed for the rear of the car, in order to improve the aerodynamics of the Sedan car. Figure 4 shows the dimensions of the spoilers that were placed at the rear.
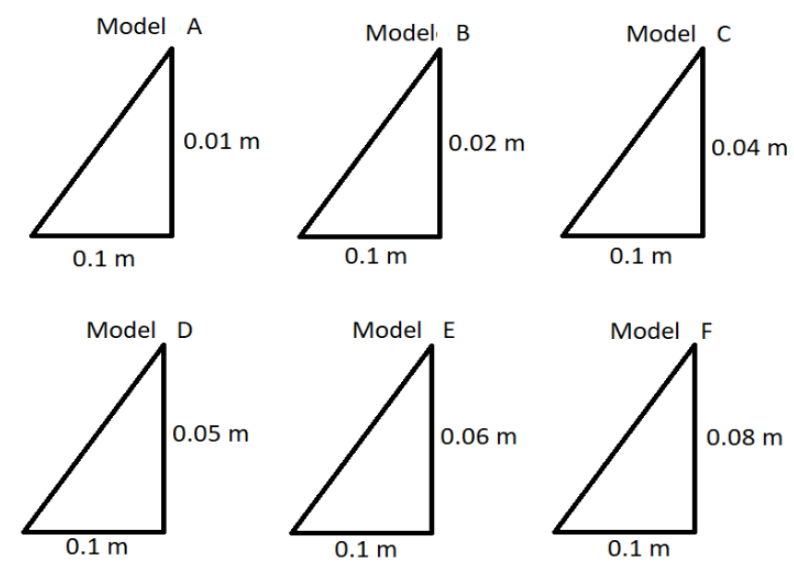

Figure 4 Lip type aileron dimensions Source: Own elaboration in Solidworks
Figure 5 shows the design of Model A with the dimensions of the base of $0.1 \mathrm{~m}$ and height $0.01 \mathrm{~m}$.

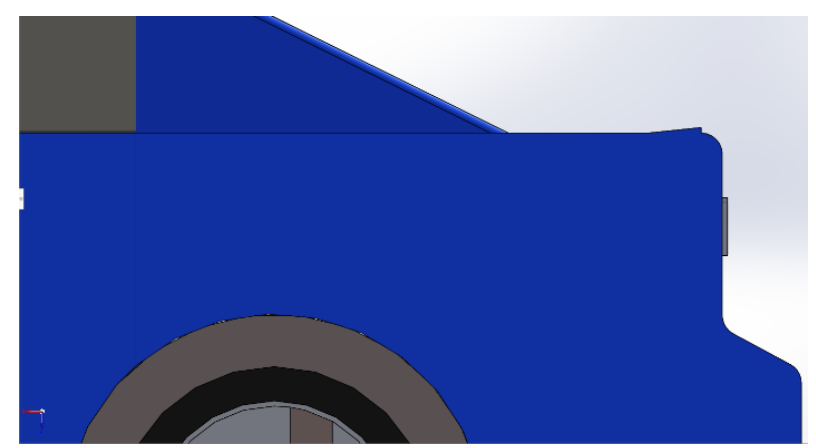

Figure 5 Lip type spoiler Model A design Source: Own elaboration in Solidworks

Figure 6 shows the design of Model B with the dimensions of the base of $0.1 \mathrm{~m}$ and height $0.02 \mathrm{~m}$.

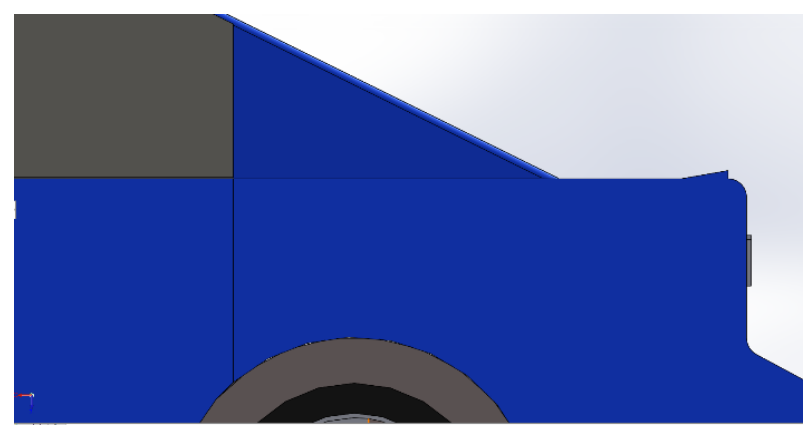

Figure 6 Lip type spoiler Model B design Source: Own elaboration in Solidworks

Figure 7 shows the design of Model $\mathrm{C}$ with the dimensions of the base of $0.1 \mathrm{~m}$ and height $0.04 \mathrm{~m}$.

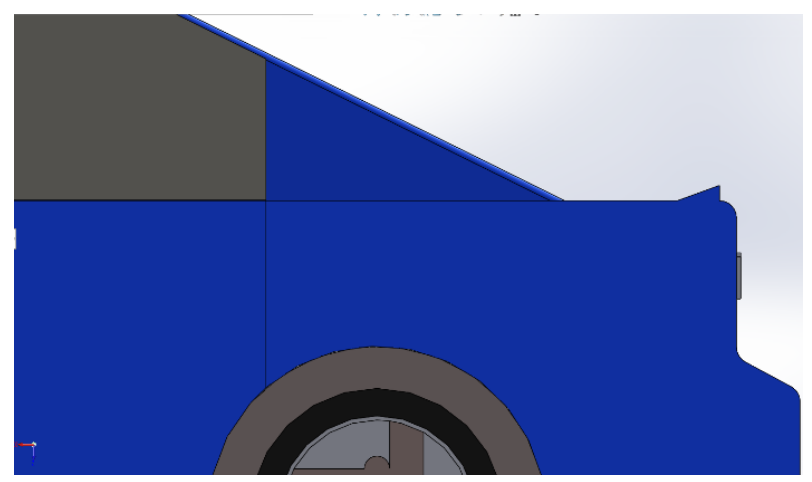

Figure 7 Lip-type spoiler Model C design Source: Own elaboration in Solidworks

Figure 8 shows the design of Model D with the dimensions of the base of $0.1 \mathrm{~m}$ and height $0.05 \mathrm{~m}$. 


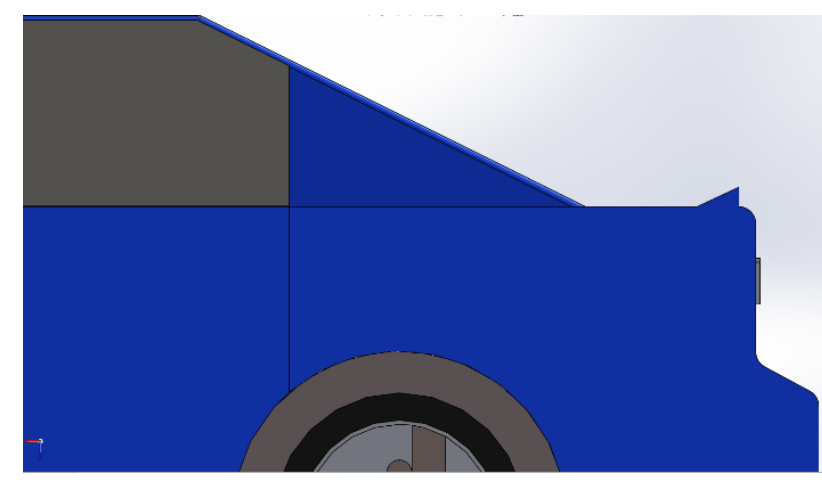

Figure 8 Lip type spoiler Model D design

Source: Own elaboration in Solidworks

Figure 9 shows the design of Model E with the dimensions of the base of $0.1 \mathrm{~m}$ and height $0.06 \mathrm{~m}$.

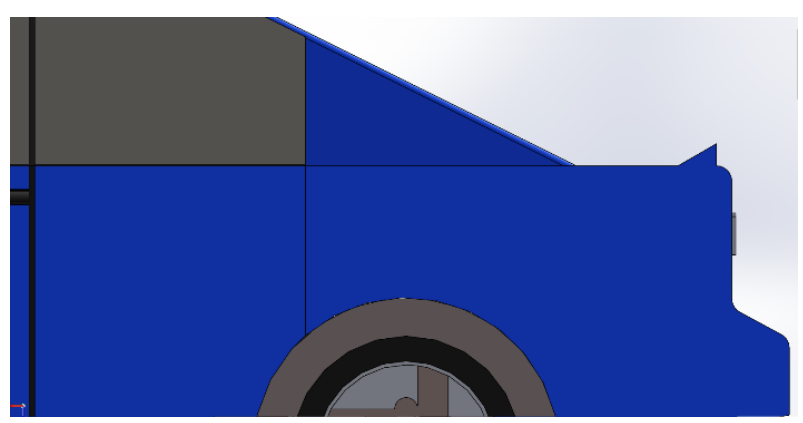

Figure 9 Lip type spoiler Model E design

Source: Own elaboration in Solidworks

Figure 10 shows the design of Model $\mathrm{F}$ with the dimensions of the base of $0.1 \mathrm{~m}$ and height $0.08 \mathrm{~m}$.

The CFD software in Solidworks has the techniques of numerical solution for finite elements using a mesh in the geometry in the fluid region. While the mesh is finer, more computing capacity is required.

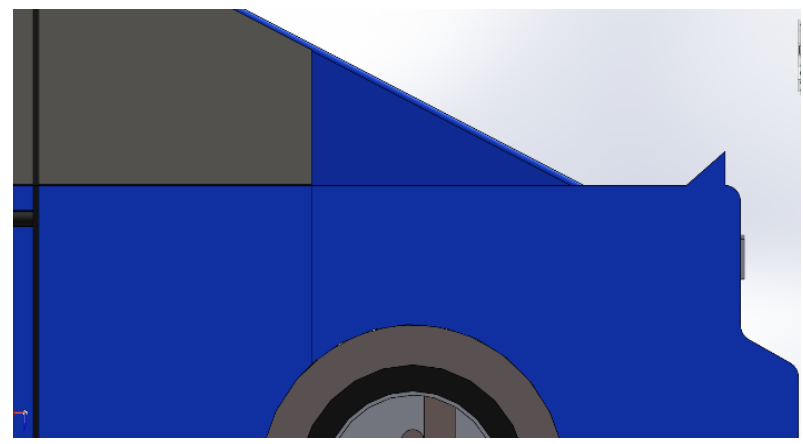

Figure 10 Lip type spoiler Model F design Source: Own elaboration in Solidworks
For this case study, a volumetric mesh is used that is formed using hexahedral cells as shown in Figure 11 in a control volume, it is generally used for external aerodynamics due to its ability to correctly define the area where the wake is formed due to the separation of the boundary layer returning to the turbulent fluid.

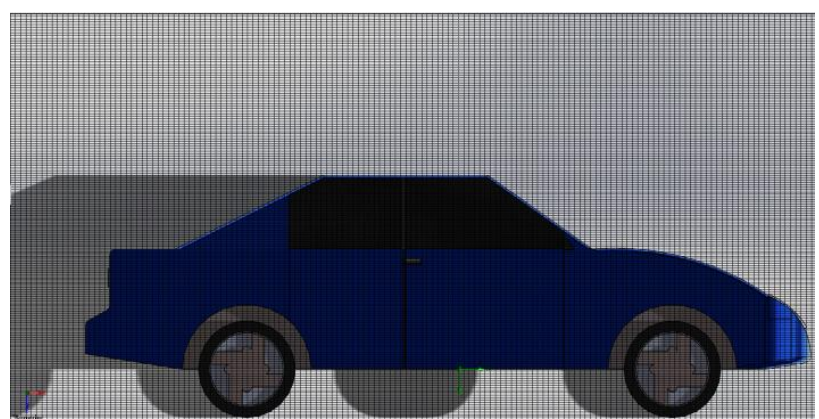

Figure 11 Control volume with 5744807 cells in the mesh Source: Own elaboration in Solidwork

The aerodynamic study that presents the flow developed around the vehicle requires a mathematical presentation, which in turn is transformed into an algorithm for its solution. This mathematical presentation is summarized in a set of conservation equations for mass, momentum, and the $\mathrm{k}-\varepsilon$ turbulence model. [30]:

The continuity equation is represented by

$\frac{\partial u}{\partial x}+\frac{\partial v}{\partial y}+\frac{\partial w}{\partial z}=0$

The Navier Stokes equations are expressed as follows [30]:

$\rho\left(\frac{\partial u}{\partial t}+u \frac{\partial u}{\partial x}+v \frac{\partial u}{\partial y}+w \frac{\partial u}{\partial z}\right)=\rho g_{x}-\frac{\partial P}{\partial x}+\mu\left(\frac{\partial^{2} u}{\partial x^{2}}+\frac{\partial^{2} u}{\partial y^{2}}+\frac{\partial^{2} u}{\partial z^{2}}\right)$

$\rho\left(\frac{\partial v}{\partial t}+u \frac{\partial v}{\partial x}+v \frac{\partial v}{\partial y}+w \frac{\partial v}{\partial z}\right)=\rho g_{y}-\frac{\partial P}{\partial y}+\mu\left(\frac{\partial^{2} v}{\partial x^{2}}+\frac{\partial^{2} v}{\partial y^{2}}+\frac{\partial^{2} v}{\partial z^{2}}\right)$

$\rho\left(\frac{\partial w}{\partial t}+u \frac{\partial w}{\partial x}+v \frac{\partial w}{\partial y}+w \frac{\partial w}{\partial z}\right)=\rho g_{z}-\frac{\partial P}{\partial z}+\mu\left(\frac{\partial^{2} w}{\partial x^{2}}+\frac{\partial^{2} w}{\partial y^{2}}+\frac{\partial^{2} w}{\partial z^{2}}\right)$

For turbulent flows, the Standard kmodelo [31] model applies:

$\frac{\partial}{\partial t}(\rho k)+\frac{\partial}{\partial x_{i}}\left(\rho k u_{i}\right)=\frac{\partial}{\partial x_{j}}\left[\left(\mu+\frac{\mu_{t}}{\sigma_{k}}\right) \frac{\partial k}{\partial x_{j}}\right]+G_{k}+G_{b}-\rho \varepsilon-Y_{m}+S_{k}$

$\frac{\partial}{\partial t}(\rho \varepsilon)+\frac{\partial}{\partial x_{i}}\left(\rho \varepsilon u_{i}\right)=\frac{\partial}{\partial x_{j}}\left[\left(\mu+\frac{\mu_{t}}{\sigma_{\varepsilon}}\right) \frac{\partial \varepsilon}{\partial x_{j}}\right]+C_{1 \varepsilon} \frac{\varepsilon}{k}\left(G_{k}+C_{3 \varepsilon} G_{b}\right)-C_{2 \varepsilon} \rho \frac{\varepsilon^{2}}{k}+S_{\varepsilon}$ 
In these equations, Gk represents the generation of turbulent kinetic energy due to average velocity gradients. $\mathrm{Gb}$ is turbulent kinetic energy generation due to buoyancy. Ym represents the contribution of fluctuating dilation in compressible turbulence at all dissipation rates. $\mathrm{C} 1 \varepsilon, \mathrm{C} 2 \varepsilon$ and $\mathrm{C} 3 \varepsilon$ are constants. $\Sigma \varepsilon$ and $\sigma \varepsilon$ are the turbulent Prantl numbers for $\mathrm{k}$ and $\varepsilon$ respectively. $\mathrm{Sk}$ and $\mathrm{S} \varepsilon$ are user-defined source terms. The turbulent viscosity $\mu \mathrm{t}$ is calculated as follows:

$\mu_{t}=\rho C_{\mu} \frac{k^{2}}{\varepsilon}$

The parameters of thesome constants are:

$\mathrm{C}_{1 \varepsilon}=1.44, \mathrm{C}_{2 \varepsilon}=1.92, \mathrm{C}_{\mu}=0.09, \sigma_{\mathrm{k}}=1.0, \sigma_{\varepsilon}=1.3$

To calculate the drag coefficient, equation (7) is used, where Fx is the drag force $(\mathrm{N}), \rho$ is the air density $\left(\mathrm{kg} / \mathrm{m}^{3}\right), \mathrm{v}$ is the air speed $(\mathrm{m} / \mathrm{s})$ and $\mathrm{A}$ is the frontal area of the car [30], for this study the area is $4.63 \mathrm{~m}^{2}$.

$C d=\frac{F x}{(1 / 2) \rho v^{2} A}$

The lift force as perceived from its inception is normal to the ground. Unlike the drag force which has the opposite direction to the direction of the vehicle. Equation (8) shows the calculation of the lift force, where Fy is the lift force:

$C l=\frac{F y}{(1 / 2) \rho v^{2} A}$

For the analysis of this work, air is used at a speed of $125 \mathrm{~km} / \mathrm{h}$ at different mesh numbers (495989, 2050308, 2971043, 3840774 and 5744807 ), the air density is $1.2 \mathrm{~kg} / \mathrm{m}^{3}$ and the viscosity is $1.8 \times 10-5$ Pa.s. With the results of the simulations, it is intended to know the drag and lift forces, then calculate the coefficients to know the best aerodynamic model with the spoiler implemented at the rear that reduces these forces compared to normal models.

\section{Results}

The results obtained through the simulations carried out in Solidworks Flow Simulation at different types of meshing (a coarse mesh to a fine mesh) were the drag and lift forces.
Figure 12 shows the drag force results of all the lip-type aileron models proposed to improve aerodynamics. Making a comparison with the finest mesh of 5744807 cells, the normal car registered a force of $560.13 \mathrm{~N}$ and the model $\mathrm{F}$ registered $579.8 \mathrm{~N}$. When the height increases in each model of the lip type aileron, the Drag Force increases.

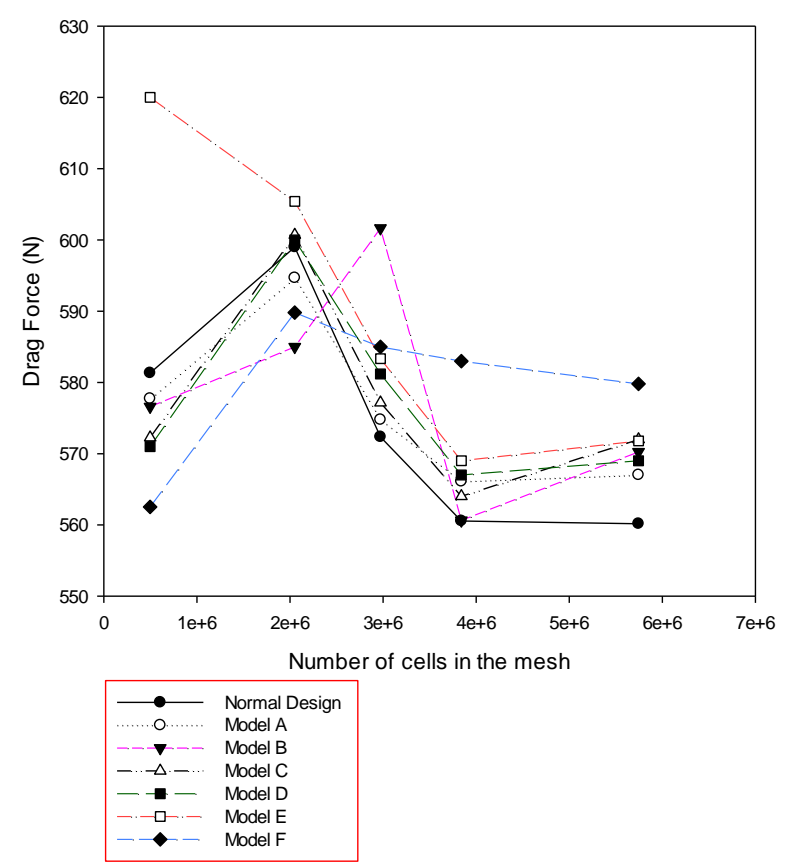

Figure 12 Drag Forces Results with a mesh refinement at $125 \mathrm{~km} / \mathrm{h}$

Source: Self made

Figure 13 shows the lift forces for each model. Comparing the results with the mesh of 5744807, the normal model registered a force of $407.34 \mathrm{~N}$ and the model $\mathrm{F}$ of $226 \mathrm{~N}$. It is observed that the lift forces decrease as the height in the aileron increases.

With the results obtained from the drag and lift forces through the simulations, the drag and lift coefficients were calculated with a mesh of 5744807 cells. Figure 14 and Table 1 show the results and the percentages of the drag coefficients for all the models. Comparing the results of the coefficients and the percentages the difference is minimal, with the implementation of the ailerons the drag coefficients increase in a range of $1,222-3,598 \%$. 


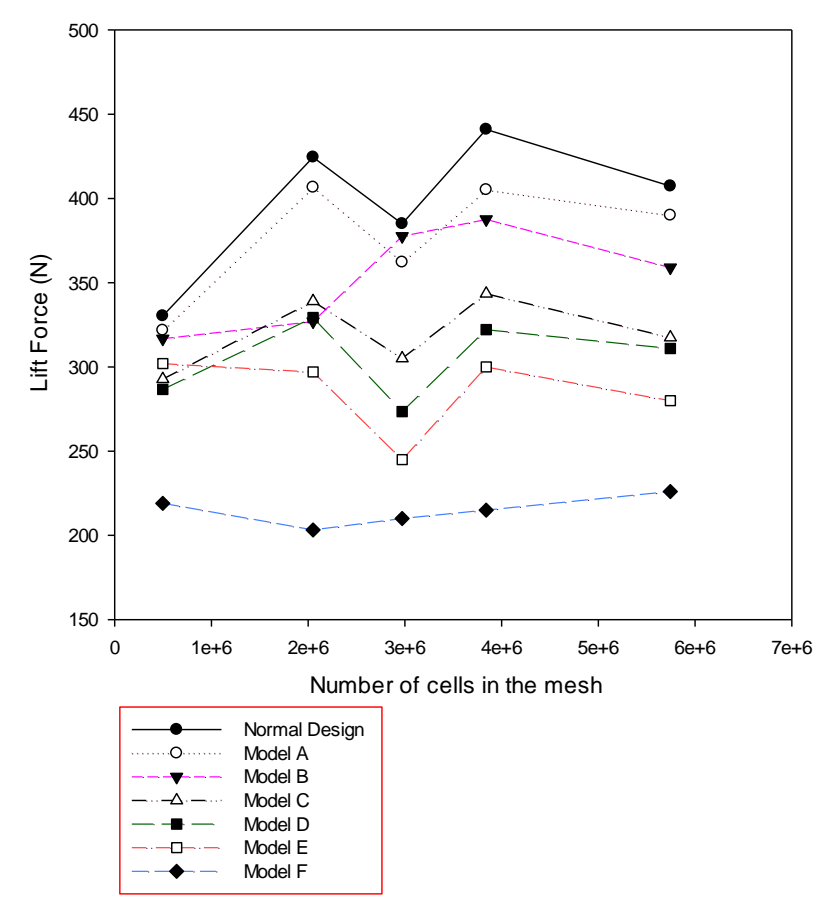

Figure 13 Results of the Support Forces with a mesh refinement at $125 \mathrm{~km} / \mathrm{h}$

Source: Self-made

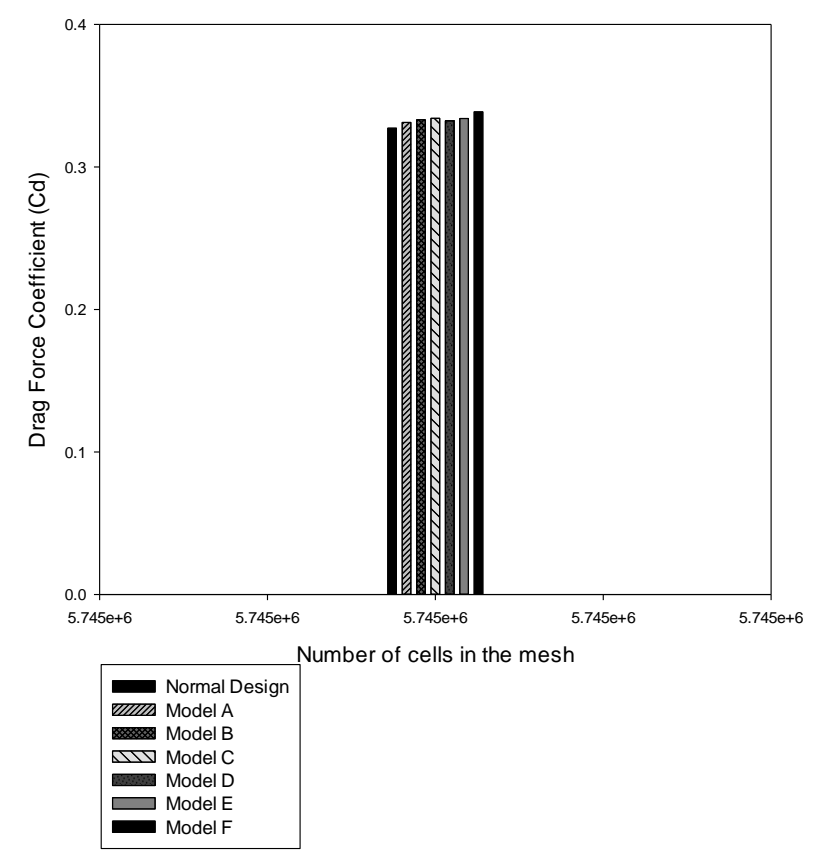

Figure 14 Results of the Drag Coefficients with 5744807 cells in the mesh at $125 \mathrm{~km} / \mathrm{h}$

Source: Self-made

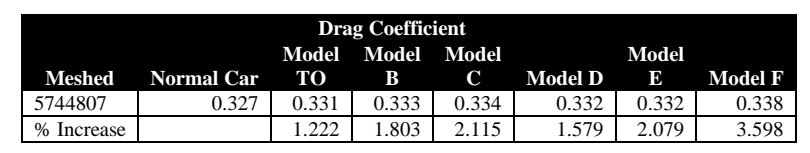

Table 1 Results of the reduction percentages of the drag coefficients

Source: Self-made
Figure 15 and Table 2 show the results of the lift coefficients with a mesh of 5744807 cells. It is observed that the coefficients of the models decrease as the height of the aileron increases. With the $\mathrm{F}$ model it is possible to reduce the lift coefficient up to $44.52 \%$. The normal car registered a value of 0.238 and it was reduced to 0.132 .

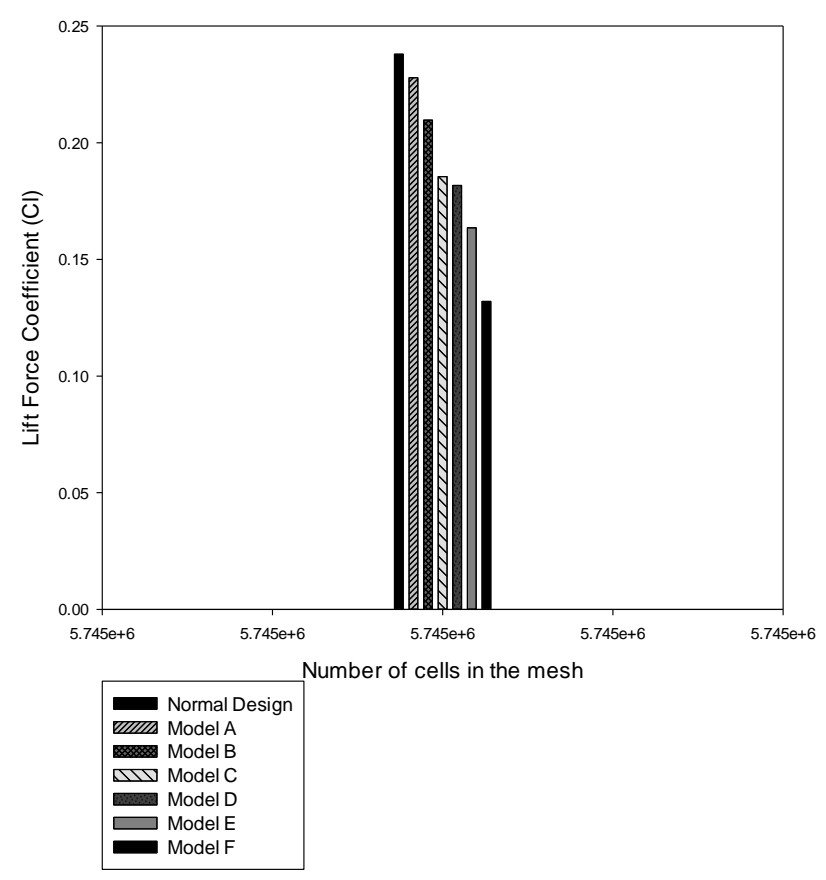

Figure 15 Results of the Support Coefficients with 5744807 cells in the mesh at $125 \mathrm{~km} / \mathrm{h}$ Source: Self-made

\begin{tabular}{|c|c|c|c|c|c|c|c|}
\hline \multirow[b]{2}{*}{ Meshed } & \multirow[b]{2}{*}{$\begin{array}{c}\text { Normal } \\
\text { Car }\end{array}$} & \multicolumn{3}{|c|}{ Coefficient of Support } & \multirow[b]{2}{*}{$\begin{array}{c}\text { Model } \\
\text { D }\end{array}$} & \multirow[b]{2}{*}{$\begin{array}{c}\text { Model } \\
\text { E }\end{array}$} & \multirow[b]{2}{*}{ Model F } \\
\hline & & $\begin{array}{c}\text { Model } \\
\text { TO }\end{array}$ & $\begin{array}{c}\text { Model } \\
\text { B }\end{array}$ & Model & & & \\
\hline 5744807 & 0.238 & 0.228 & 0.21 & 0.185 & 0.181 & 0.163 & 0.132 \\
\hline $\begin{array}{l}\% \\
\text { Reduction }\end{array}$ & & 4.25 & 11.86 & 22.05 & 23.65 & 31.26 & 44.52 \\
\hline
\end{tabular}

Table 2 Percentages of reduction of lift coefficients Source: Self-made

Figures 14, 15, 16, 17, 18 and 19 show the speed contours for the proposed models of lip-type ailerons implemented in the rear simulated at the speed of $125 \mathrm{~km} / \mathrm{h}$. The formation of wakes formed by vortices at low speeds is observed that cause the pressure to decrease and the detachment of the turbulent boundary layer takes place at a farther distance, therefore this effect causes the lift forces to decrease. 


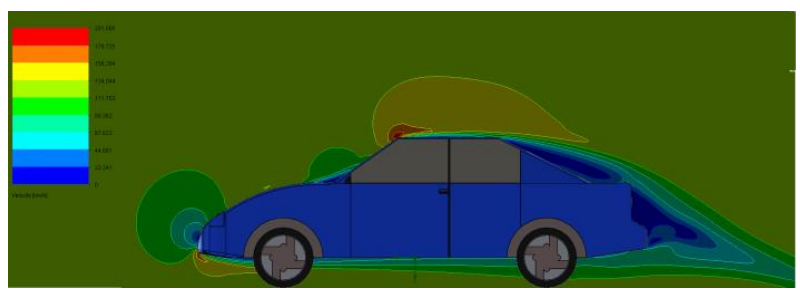

Figure 14 Results of the velocity contours of Model A with 5744807 cells in the mesh

Source: Own elaboration in Solidworks

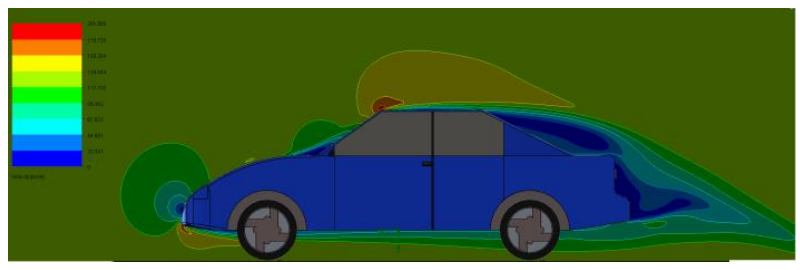

Figure 15 Results of the velocity contours of Model B with 5744807 cells in the mesh

Source: Own elaboration in Solidworks

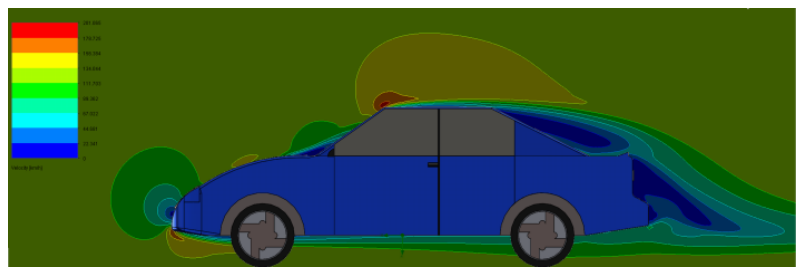

Figure 16 Results of the velocity contours of Model C with 5744807 cells in the mesh

Source: Own elaboration in Solidworks

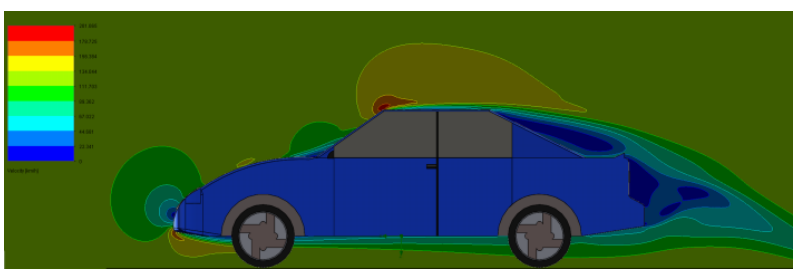

Figure 17 Results of the velocity contours of Model D with 5744807 cells in the mesh

Source: Own elaboration in Solidworks

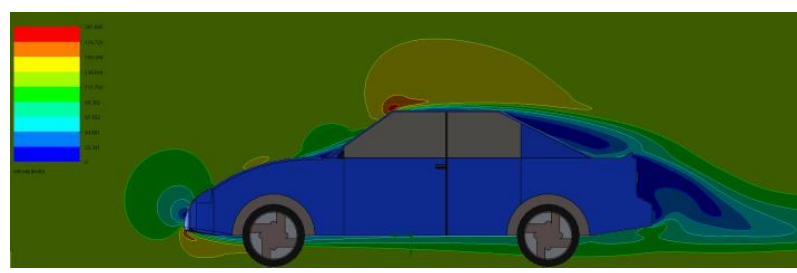

Figure 18 Results of the velocity contours of Model E with 5744807 cells in the mesh

Source: Own elaboration in Solidworks

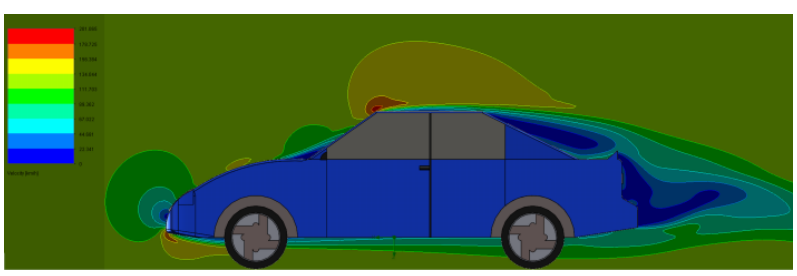

Figure 19 Results of the velocity contours of Model F with 5744807 cells in the mesh

Source: Own elaboration in Solidworks

ISSN-2531-2189

ECORFAN ${ }^{\circledR}$ All rights reserved.

\section{Conclusions}

By implementing the different models of ailerons at the rear of the car, it is possible to reduce the lift coefficient up to $44.5 \%$ with the $F$ model $(0.1 \mathrm{~m}$ base with $0.08 \mathrm{~m}$ height $)$, with the same model $\mathrm{F}$ the drag coefficient increases. up to $3.5 \%$ which is not highly recommended to increase this force. Using a spoiler attachment on a normal car improves aerodynamics and provides greater stability when cornering or on a normal path on the road. Therefore, these coefficients are affected by the design and dimensions of the car.

On the part of the computer equipment, while the mesh is finer, the longer it will take to solve the simulation and the results will be more exact to reality depending on the characteristics of the computer.

\section{References}

[1] Howell J., Le Good G., 1999. The influence of aerodynamic lift on high-speed stability. SAE paper No. 1999-01-0651.

[2] Okada Y., Nouzawa T., Nakamura T., Okamoto S., 2009. Flow structure above the trunk deck of Sedan-Type vehicles and their influence on high-speed vehicle stability first report: On-road and wind tunnel studies on unsteady flow characteristics that stabilize vehicle behavior. SAE paper No. 2009-01-0004.

[3] Coleman S. A; Baker C. J; 1990. High sided road vehicles in cross wind. Journal Wind Engineering Industrial Aerodynamic. 36, 1383-1392.

[4] Coleman S. A; Baker C. J; 1994. An experimental study of the aerodynamic behavior of high sided lorries in cross wind. Journal Wind Engineering Industrial Aerodynamic.53, 401-429.

[5] Baker J. C; 1991. Ground vehicles in high cross wind. 1. Steady aerodynamic forces. Journal Fluids Structure. 5, 69-90.

[6] Baker J. C; 1991. Ground vehicles in high cross wind. 2. Steady aerodynamic forces. Journal Fluids Structure. 5, 91-111.
HORTELANO-CAPETILLO, Juan Gregorio, MARTÍNEZ VÁZQUEZ, J. Merced, ZUÑ̃IGA-CERROBLANCO, José Luis and RODRIGUEZ-ORTIZ, Gabriel. Analysis of drag and lift forces for a sedan car using a rear lip spoiler. Journal of Mechanical Engineering. 2020 
[7] Quinn A. D; Sterling M; Robertson A. P; Baker J. C; 2007. An investigation of the wind induced rolling moment on a commercial vehicle in the atmospheric boundary layer. Proceedings of the Institution of Mechanical Engineers, Part D: Journal of Automobile Engineering. 221, 1367-1379.

[8] Cheli F; Corradi R; Sabbioni E; Tomasini G; 2011. Wind tunnel test on heavy road vehicles: cross wind induced loads Part 1. Wind Engineering Industrial Aerodynamic. 99, 1000-1010.

[9] Beaudoin J. F; Aider J. L; 2008. Drag and lift reduction of a $3 D$ bluff body using flaps. Experiment in Fluids. 44 (4), 491.

[10] Fourrié G; Keirsbulk L; Labraga L; Gilliéron P; 2011. Bluff body drag reduction using a deflector. Experiment in Fluids. 50 (2), 385-395.

[11] Hanfeng W; Yu Z; Chao Z; Xuhui H; 2016. Aerodynamic drag reduction of an Ahmed body based on deflectors. Journals Wind Engineering Industrial Aerodynamic. 148, 34-44.

[12] Grandemage M; Mary A; Gohlke M; Cadot $\mathrm{O} ;$ 2013. Effect on drag of the flow orientation at the base separation of a simplified blunt road vehicle. Experiment in Fluids. 54 (5), 1529.

[13] Urquhart M; Sebben S; Sterken L; 2018. Numerical analysis of a vehicle wakes with tapered rear extensions under yaw conditions. Journal Wind Engineering Aerodynamic. 179, 308-318.

[14] Littlewood R. P; Passmore M; 2010. The optimization of roof trailing edge geometry of a simple square back. (No. 2010-01-0510) (SAE Technical Paper).

[15] J. P. Howell. The influence of ground simulation on aerodynamic of simple car shapes with an underfloor diffuser. Conference on vehicle aerodynamics. Royal Aerodynamic Society. 1994.
[16] Cooper K. R; Bertenyi T; Dutil G; Syms J; Sovran G. 1998. The aerodynamics performance of automobile underbody diffuser. SAE Technical Paper 980030.

[17] Xingjun Hu; Rui Zhang; Jian Ye; Xu Yan; Zhiming Zhao; 2011. Influence of different diffuser angle on sedan aerodynamic characteristics. Physics Procedia. 22. 239245.

[18] Gilhaus, R. Hoffmann. "Directional Stability, Aerodynamic od Road Vehicles, in: W.H. Hucho (Ed), SAE International, Warrendale. PA, 1998.

[19] J.R. Callister, A.R. George, Wind Noise, Aerodynamics of Road Vehicles, in: W.H. Hucho (Ed.), SAE International, Warrendale, PA, 1998.

[20] F.R. Bailey, H.D. Simon, Future Directions in Computing and CFD, AIAA Paper 922734, 1992.

[21] H. Taeyoung, V. Sumantran, C. Harris, T. Kuzmanov, M. Huebler, T. Zak, Flowfield simulations of three simplified vehicle shapes and comparisons with experimental measurements, SAE Transactions 106 (1996) 820835.

[22] S. Y. Cheng; M. Tsubokura; Y. Okada; T. Nouzawa; T. Nakashima; D. H. Doh; 2013. Aerodynamic stability of road vehicles in dynamic pitching motion. Journal Wind Engineering and Industrial Aerodynamics. 122 (2014), 146-156.

[23] S. M. Rakibul Hassan, Toukir Islam, Mohammad Ali, Md. Quamrul Islam. "Numerical Study on Aerodynamic Drag Reduction of Racing Cars". Procedia Engineering 90 (2014) 308-313.

[24] Rubel Chandra Das, Mahmud Riyad, " $C F D$ Analysis of Passenger Vehicleat Various Angle of Rear End Spoiler". Procedia Engineering 194 (2017) 160-165.

[25] D. E. Aljure; J. Calafell; A. Baez; A. Oliva; 2018. Flow over a realistic car model: Wall modeled large eddy simulations assessment and unsteady effects. Journal Wind Engineering Industrial Aerodynamics. 174 (2018), 225-240. 
[26] Krzysztof Kurec, Michal Remer, Tobiasz Mayer, Sylwester Tudruj, Janusz Piechna. "Flow control for a car-mounted rear wing". International journal of Mechanical Sciences. Volume 152 (2019) 384-399.

[27] Vignesh S; Vikas Shridhar Gangad; Jishnu V; Maheswarreddy; Amal Krishna; Yagna S. Mukkamala; 2019. Windscreen angle and hood inclination optimization for drag reduction in cars. Procedia Manufacturing. 30 (2019), 685-692.

[28] Mario Rüttgers; Junshin Park; Donghyun You; 2019. Large-eddy simulation of turbulent flow over the DrivAer fastback vehicle model. Journal Wind Engineering Industrial Aerodynamics. 186 (2019), 123-138.

[29] Emil Ljungskog; Simone Sebben; Alexander Broniewicz; 2020. Inclusion of the physical wind tunnel in vehicle CFD simulations for improved prediction quality. Journal Wind Engineering Industrial Aerodynamics. 197 (2020), 104055.

[30] Introduction to Fluid Mechanics, Sixth Edition, (2003). Robert W. Fox, Alan T. MacDonald, Philip J. Pritchard.

[31] V. Yakhot and L. M. Smith. The renormalization group, the $\varepsilon^{-}$ expansion and derivation of turbulence models. Journal of Scientific Computing, Vol. 7, no. 1, pp. 35-61, 1992. 